\title{
Cambrian-Ordovician conodonts from slump deposits of the Argentine Precordillera: new insights into its passive margin development
}

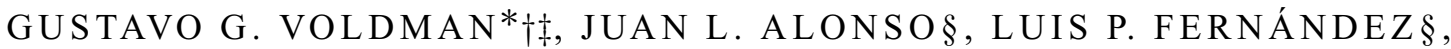 \\ ALDO L. BANCHIGף, GUILLERMO L. ALBANESI* ${ }^{*}$, GLADYS ORTEGA* \\ \& RAÚL CARDÓđII \\ * CONICET, Museo de Paleontología, CIGEA, Facultad de Ciencias Exactas, Físicas y Naturales, Universidad Nacional \\ de Córdoba, X5016GCB Córdoba, Argentina \\ †CICTERRA (CONICET-UNC), Córdoba, Argentina \\ $\S$ Departamento de Geología, Universidad de Oviedo, 33005 Oviedo, Spain \\ qFacultad de Ciencias Exactas y Naturales, Universidad Nacional de San Juan, 5400 San Juan, Argentina \\ ||Servicio Geológico Minero Argentino (SEGEMAR), 5400 San Juan, Argentina
}

(Received 22 January 2016; accepted 26 July 2016)

\begin{abstract}
The Los Sombreros Formation represents the western continental margin slope deposits of the Argentine Precordillera, a sub-terrane accreted to Gondwana as part of the Cuyania Terrane in early Palaeozoic times. The age of these gravity-driven deposits is controversial and, therefore, a precise biostratigraphic scheme is essential to reveal the evolution of the continental margin. New conodont samplings along with sedimentological and structural analysis carried out in the Los Sombreros Formation in the La Invernada Range provide clues to its depositional framework. The sedimentary succession is made up of dominantly calciturbidites, carbonate breccias and conglomerates, along with mudstones that represent the pelagic/hemipelagic background sedimentation. It displays hectometric to outcrop-scale slump folds with variable hinge-line orientations and pinch-and-swell structures, evidencing soft-sediment deformation, consistent with a slope to base-of-slope setting. Three limestone samples from this succession include conodonts referable to the pandemic Hirsutodontus simplex Subzone of the Cordylodus intermedius Zone (upper Furongian, Cambrian) and from the Macerodus dianae Zone (upper Tremadocian, Ordovician), implying that a slope connected the shallow-water shelf with a deep-water (oceanic) basin at least since late Cambrian times. The conodont faunas show affinities to coeval assemblages from outer shelf and slope environments around Laurentia yet they are not conclusive to postulate a geographic origin for the Precordillera. The thermal alteration of the conodonts is consistent with sedimentary burial and nappe stacking in this sector of the Precordillera.
\end{abstract}

Keywords: conodont, slope facies, slump, Los Sombreros Formation, Argentine Precordillera, Cambrian, Ordovician.

\section{Introduction}

In the external zone of the Andean orogen, the Argentine Precordillera records a series of tectonostratigraphic events related to the building of Gondwana during early to middle Palaeozoic times (e.g. Cawood, 2005; Rapela et al. 2016). Eastern, Central and Western domains have classically been distinguished after their structural and stratigraphic features (Ortiz \& Zambrano, 1981; Baldis et al. 1982). The Eastern and Central Precordillera involve a large passivemargin carbonate platform, Cambro-Ordovician in age, which is overlain by Middle Ordovician siliciclastic foreland-basin deposits that reach up to the Devonian Punta Negra Formation. Conversely, the Western Precordillera exhibits a deep-water succession, with ocean-floor sedimentary rocks containing pillow lavas and mafic-ultramafic bodies in the westernmost sections.

†Author for correspondence: gvoldman@unc.edu.ar
The transition between the Central and Western Precordillera is represented by the disorganized deposits of the Los Sombreros Formation (Cuerda, Cingolani \& Varela, 1983; Banchig, Keller \& Milana, 1990) and the Corralito Formation (Furque \& Caballé, 1988; Furque et al. 1990), recording the slope of a continental margin. However, the complex structure and the scarcity of fossils challenge against a precise depositional scheme, whilst Ordovician and Devonian ages have been proposed for the Los Sombreros Formation (e.g. Benedetto \& Vaccari, 1992; Voldman, Albanesi \& Ramos, 2009; Peralta, 2013). For instance, Peralta (2013) considered that all the disorganized deposits slid in Devonian times, after sedimentation of the Punta Negra Formation. Thus, constraining the spatio-temporal framework of the mélanges is essential for understanding the geotectonic evolution of the passive continental margin of the early Palaeozoic Precordillera.

In the present study, new conodont findings along with structural, stratigraphic and sedimentological data 


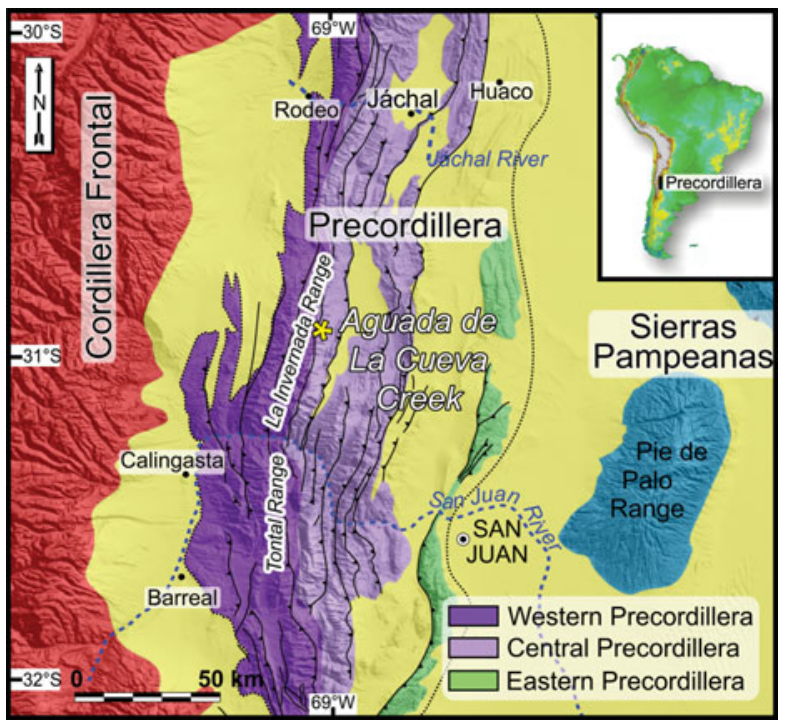

Figure 1. (Colour online) Location map of the Argentine Precordillera fold-and-thrust belt showing the studied locality and the western, central and eastern morphostructural domains. Base image derived from Shuttle Radar Topography Mission (SRTM).

for the Los Sombreros Formation in the La Invernada Range are presented. The record of the Hirsutodontus simplex Subzone of the Cordylodus intermedius Zone (upper Furongian, Cambrian) and the Macerodus dianae Zone (upper Tremadocian, Ordovician) in gravity-flow deposits with synsedimentary deformation features suggests the existence of a slope in late Cambrian - Early Ordovician times. Moreover, the defined high-resolution conodont biostratigraphy improves the intrabasinal correlation with the Precordilleran carbonate platform as well as with other regions of the world.

\section{Geological setting}

The Argentine Precordillera of La Rioja, San Juan and Mendoza provinces is a $c$. $80 \mathrm{~km}$ wide foreland foldand-thrust belt that involves Palaeozoic to Cenozoic rocks, which extends between $29^{\circ}$ and $33^{\circ} \mathrm{S}$ in the Andean foothills above the shallow subduction segment of the Nazca plate (Heim, 1952; Allmendinger et al. 1990; Gosen, 1992; Ramos, Cristallini \& Pérez, 2002) (Fig. 1). The Precordilleran Cambrian-Ordovician carbonate platform sequence is unique to South America and makes up part of a larger region of the Andean foothills of western Argentina that is referred to as the Cuyania composite terrane (Ramos, 1995).

At the continental slope and rise, to the west of the Precordilleran carbonate platform, the Los Sombreros mélange is a mudstone-dominated deep-water disorganized unit, containing a diverse array of rocks derived from the platform, the slope and the basement. These rocks include arkosic sandstones, megabreccias, conglomerates with well-rounded basement-derived metamorphic and igneous pebbles to boulders, thin-bedded fine-grained limestones, carbonate breccias and blocks up to several hectometres in size of lower Cambrian to
Lower Ordovician limestones displaying platform facies not represented elsewhere (e.g. Bordonaro, 2003).

The Los Sombreros Formation displays ubiquitous extensional structures that result in block-in-matrix fabric in some places as a consequence of submarine sliding (Alonso et al. 2008). The main outcrop belt of the mélange extends along the eastern flank of the Tontal Range (Fig. 1), where the formation is more than $1000 \mathrm{~m}$ thick in the Seca Creek type section (Cuerda, Cingolani \& Varela, 1983; Cuerda et al. 1986). The outcrops continue patchily to the north up to the Jáchal River area (Benedetto \& Vaccari, 1992), whereas its southern prolongation is represented by the Estancia San Isidro Formation in Mendoza, which exhibits giant Cambrian limestone blocks enclosed in a green shaly matrix of Darriwilian age (Keller, 1999; Heredia \& Beresi, 2004; Ortega et al. 2007). Thus, the slope facies of the Precordillera extends over $300 \mathrm{~km}$ with N-S orientation (Fig. 1).

\section{Previous biostratigraphic studies of the Los Sombreros Formation}

The Los Sombreros Formation was originally referred to the Lower Ordovician Series based on graptolite records from its lower third (Cuerda et al. 1985). Later trilobite findings revealed the presence of lower and middle Cambrian rocks (Bordonaro \& Baldis, 1987; Bordonaro \& Banchig, 1990), interpreted as outerplatform resedimented blocks in a Lower - Middle Ordovician succession with autochthonous conodonts and graptolites (Benedetto \& Vaccari, 1992; Bordonaro, 2003). Lehnert (1994) described the first conodont assemblage of the Cordylodus proavus Zone (upper Furongian) in the Precordillera, from outcrops of the Los Sombreros Formation in the Tontal Range. The conodont association includes Cordylodus primitivus Bagnoli, Barnes \& Stevens, Cordylodus proavus Müller and Eoconodontus notchpeakensis Miller. These conodont elements derive from a calcisiltite lens that overlies shales with graptolite specimens that demonstrate its allochthonous character.

Albanesi, Ortega \& Hünicken (1995) proposed that the conformable stratigraphic contact between the Los Sombreros Formation and the overlying Yerba Loca Formation at Ancaucha Creek, $10 \mathrm{~km}$ northwest of Jáchal city, is early Darriwilian in age. They determined that the top of the Los Sombreros Formation at this locality is lower Darriwilian at the most, by considering the presence of the index conodont Baltoniodus clavatus Stouge \& Bagnoli from the basal beds of the Yerba Loca Formation and the absence of the key species Paroistodus horridus (Barnes \& Poplawski), which appears $c .40 \mathrm{~m}$ above the Yerba Loca base.

Further fossil findings include upper Cambrian, Tremadocian, Floian and Darriwilian conodont faunas (Voldman, Albanesi \& Ramos, 2009; Voldman et al. 2014) as well as graptolites referable to the uppermost Tremadocian, Floian and Sandbian stages (e.g. A. L. Banchig, unpub. Ph.D. thesis, Univ. Nacional San Juan, 


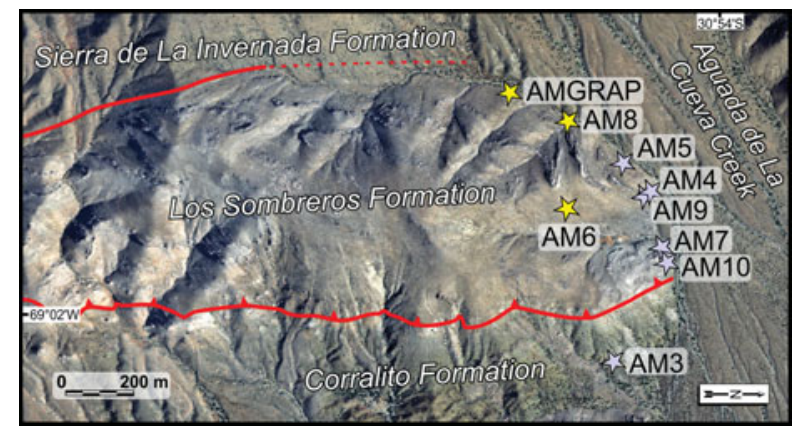

Figure 2. (Colour online) Geological map of the study area with fossiliferous sampling points.

1995; Banchig \& Moya, 2002; Ortega et al. 2014). Additionally, Astini, Thomas \& Yochelson (2004) identified the enigmatic fossil Salterella maccullochi (Murchison) in the Ancaucha Olistolith of the Los Sombreros Formation, composed of inner-shelf deposits that they interpreted as lower Cambrian synrift strata.

\section{Study area and methods}

The La Invernada Range constitutes a critical region to investigate the architecture and kinematic development of the disorganized deposits of the Los Sombreros Formation. This range lies to the north of the Tontal Range, extending for $c$. $60 \mathrm{~km}$ with a N-S trend (Fig. 1). It displays E-verging thrusts and related folds, involving a lower Palaeozoic succession that also includes the Siluro-Devonian mélange deposits of the Corralito Formation, which crop out exclusively in this range. In order to determine the age of the Los Sombreros Formation at the Aguada de La Cueva Creek section (Fig. 2), nine limestone samples (14 kg in total) were collected and processed following the standard techniques to recover conodont elements (Stone, 1987). Three samples were productive, yielding 80 specimens that are housed under the repository codes CORD-MP 50734 to 50814 in the Museo de Paleontología, Facultad de Ciencias Exactas, Físicas y Naturales, Universidad Nacional de Córdoba, Argentina. Field work also included structural mapping and stratigraphic and sedimentological studies, during which kinematic data were acquired and rocks were described in terms of their bedding and lithology and sampled for thin-section preparation.

\section{Results}

\section{5.a. Stratigraphy and structure}

In the Aguada de La Cueva Creek area, the Los Sombreros Formation consists of a c. 500-600 m thick succession of dominantly limestones, carbonate breccias and conglomerates and subordinate shales (Fig. 2). The limestones are thin bedded, varying from peloidal/calcisphere mudstones and wackestones to graded and laminated calclithites (calciturbidites) (Fig. 3a, b), which may pass upwards into a shale divi- sion and gradationally overlie a breccia/conglomerate division. Breccias/conglomerates contain mainly clasts of mudstones, peloidal grainstones and recrystallized limestones, with minor amounts of chert and quartz clasts. They constitute beds that are massive or graded, and that may be gradationally overlain by a calciturbidite; some exceptional examples of stratified (laminated) beds also occur (Fig. 3c). The whole succession lacks in situ shallow-water faunas, with the exception of scarce lingulids, and exhibits slight bioturbation restricted to the peloidal/calcisphere limestones. Remarkably, it displays hectometric slump folds, extensional faults and lateral transitions between intact and faulted/brecciated beds (Fig. 3a, d).

As a whole, most of these facies are indicative of sedimentation from gravity flows, from cohesive debris flows to low-density turbidity currents (see Lowe, 1982; McIlreath \& James, 1984; Mutti et al. 1999, amongst others). Fine-grained, peloidal/calcisphere mudstones probably represent the pelagic/hemipelagic background sedimentation. This interpretation is compatible with the synsedimentary deformation features (see also Section 5.a.1. below), all indicating a slope to base-of-slope setting. The relatively deep-water environment is also suggested by the absence of in situ shallow-water fauna and the scarcity of bioturbation.

The slumped succession at the Aguada de La Cueva Creek section is unconformably overlain by grey shales with poorly preserved graptolites, including Archiclimacograptus sp., Dicellograptus sp., Dicranograptus sp., Nemagraptus sp. and Reteograptus speciosus Harris, which suggest a late Darriwilian to Sandbian age for the upper part of the Los Sombreros Formation in this area (Sample AMGRAP, Figs 2, 4). These graptolitic shales are in turn unconformably overlain by sandstone-mudstone alternations with scarce calcarenites and interbedded conglomerates and calcareous breccias of the Sierra de La Invernada Formation (Furque et al. 1990), which are Middle-Late Ordovician in age (Ortega et al. 2008).

The Los Sombreros Formation is carried on a Wdipping thrust surface onto the Siluro-Devonian Corralito mélange (Fig. 2), which comprises greenish grey shales and coquinas with extensional features, such as boudins, as well as limestone blocks of the San Juan Formation. The thrust surface displays $C^{\prime}$-type shear bands and striations, recording an eastward movement of the hanging wall. It is probably Andean in age because it is located at the toe of the Invernada Range and therefore should have been responsible for the uplift of this modern geomorphic feature. However, this thrust could be the result of rejuvenation of an older Chanic or Gondwanic thrust during Andean times, which commonly occurs in the Argentine Precordillera (Ramos, Vujovich \& Dallmeyer, 1996; Alonso et al. 2005).

\section{5.a.1. Synsedimentary deformation}

Regarding the internal structure of the Los Sombreros Formation, the most conspicuous features in the study 

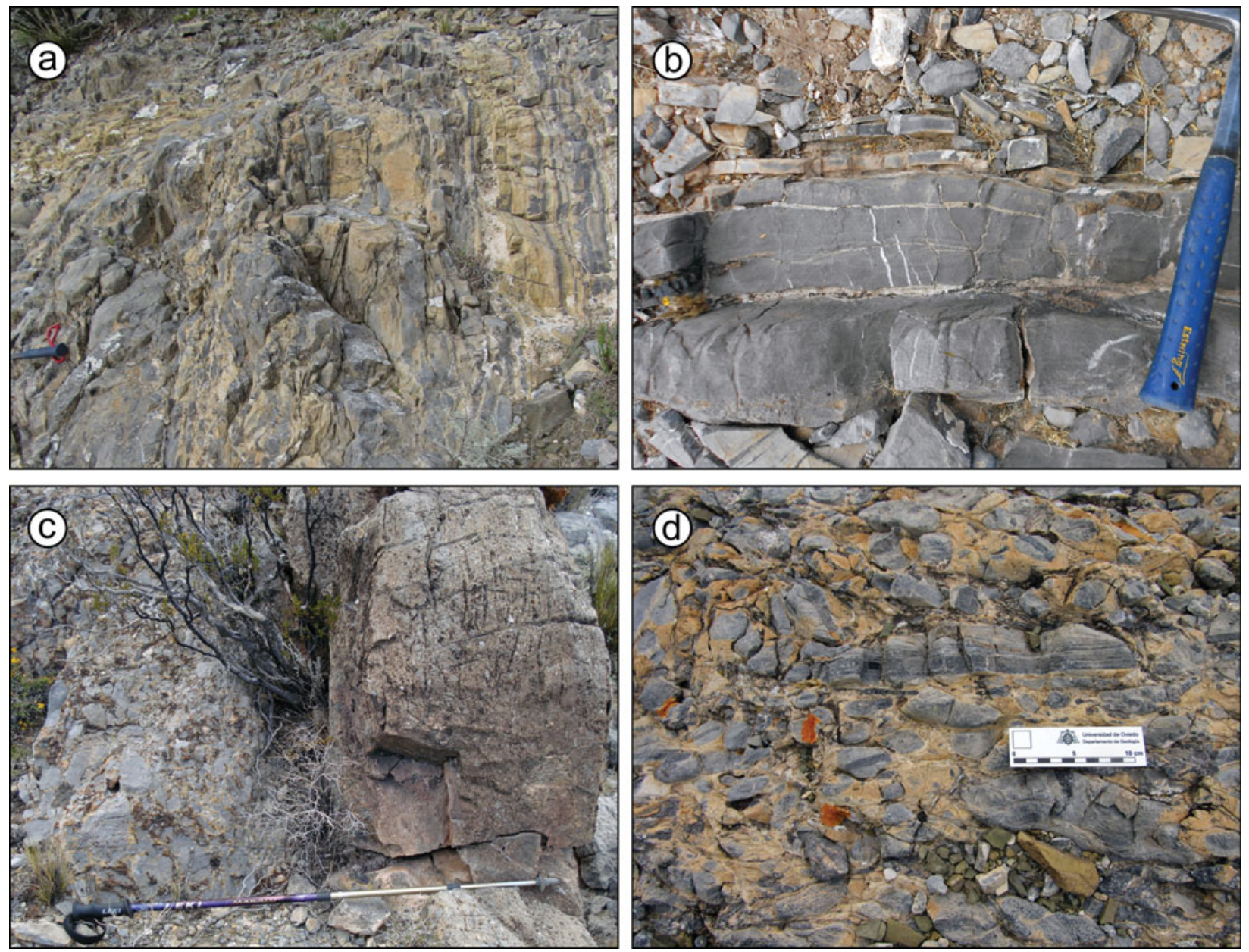

Figure 3. (Colour online) Field photographs of selected deposits from the Los Sombreros Formation at the Agua de la Cueva Creek. (a) Detail of an interval made of pebble-to-cobble breccias (left of photograph) and thin-bedded limestones (laminated mudstones and graded and laminated calciturbidites). Notice the local disruption of bedding, which laterally passes into undisturbed bedding. Stratigraphic top towards the left. (b) Interval formed of calciturbidites and variably laminated, slightly bioturbated mudstones with peloids and calcispheres. The lowermost bed is a graded calciturbidite evolving from a basal fine-pebble-bearing granulestone to a sand-grade division, whose upper part is faintly laminated and displays smooth undulations. Younging direction is to the top of the photograph. Hammer handle for scale $c .19 \mathrm{~cm}$ long. (c) Poorly sorted boulder-to-pebble carbonate breccia/conglomerate, displaying two divisions, a lower graded division and an upper laminated division. Walking pole is $c .120 \mathrm{~cm}$ long. Stratigraphic top towards the right. (d) Close-up of an interval made of thin-bedded lime mudstones, commonly laminated, with a variable degree of folding and bed disruption and brecciation. Bedding in the area is parallel to the bed above the scale, which is almost intact. The yellowish matrix surrounding the clasts is mainly dolomitic. Younging direction is to the top of the photograph.

area are hectometric folds that can be interpreted as slump structures (Fig. 2). These folds do not involve the overlying Sierra de La Invernada Formation. As well, most of the smaller, outcrop-scale structures are slump folds with variable hinge-line orientations and pinch-and-swell structures, which record soft-sediment deformation (Fig. 5). Tension fractures perpendicular to bedding and normal faults also occur. In the example of Figure 5a, b, tension fractures are restricted to the yellowish beds, indicating that these beds underwent brittle behaviour, while other beds, with pinchand-swell boudinage, were stretched by more ductile deformation, probably because the yellowish beds were more lithified. So, pinch-and-swell boudins and tension and shear fractures are more or less coeval and all of them imply bed-parallel extension. Although the development of the slump fold in Figure 5a, b is prior to extensional deformation (both fold limbs are truncated by a normal fault), all the above mentioned structures support the interpretation that gravitational collapse and sliding was the cause of the deformation. In Figure 5d, the cut-off lines of the tension fractures (blue) are parallel to the boudin necks lineation (red), recording the same extension direction.

\section{5.b. Conodont fauna and biostratigraphy}

Three carbonate samples taken at the Aguada de La Cueva Creek section yielded conodonts, which constrain the age of the slump deposits of the Los Sombreros Formation with a high-resolution biostratigraphy and improve the conodont biozonation scheme of the Precordillera. The taxonomy of the identified species is well known, following descriptions of previous authors; therefore, only a brief discussion is presented herein. 


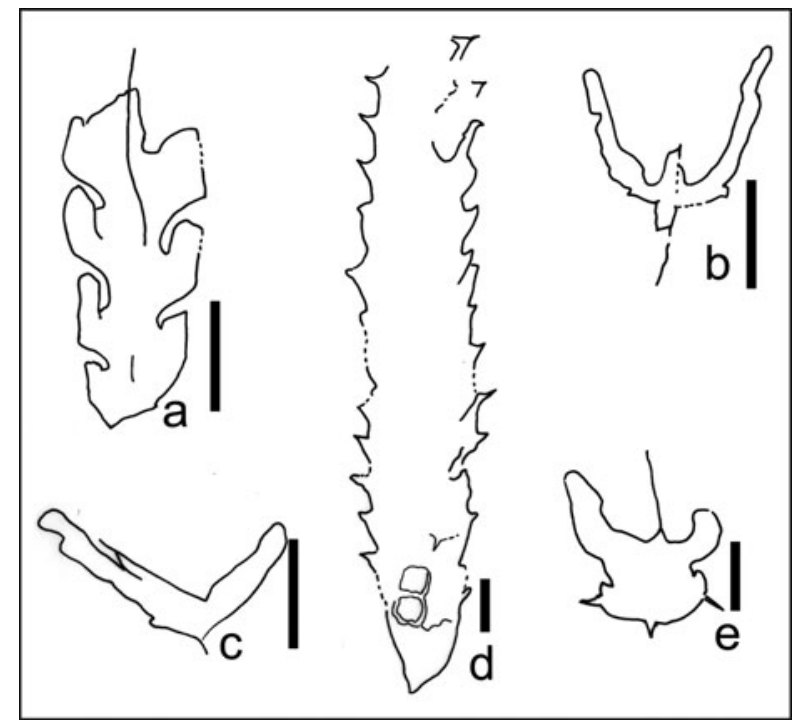

Figure 4. Late Darriwilian to Sanbian graptolites from the upper levels of the Los Sombreros Formation (Sample AMGRAP, see location in fig. 2). (a) Archiclimacograptus sp., CORD-PZ 25705; (b) Dicellograptus sp., CORD-PZ 25706; (c) Reteograptus speciosus Harris, CORD-PZ 25707; (d) Nemagraptus sp., CORD-PZ 25708; (e) Dicranograptus? sp., CORD-PZ 25709. Scale bar: $1 \mathrm{~mm}$.
A lime mudstone affected by synsedimentary extensional faults (sample AM6) yielded Cordylodus caboti Bagnoli, Barnes \& Stevens, C. cf. tortus Barnes, $C$. intermedius Furnish, C. proavus Müller, C. cf. andresi Viira \& Sergeyeva, Drepanoistodus sp., Teridontus nakamurai (Nogami), Variabiloconus datsonensis (Druce \& Jones), Westergaardodina sp. and the index species Hirsutodontus simplex (Druce \& Jones) (Fig. 6). The latter species is chronostratigraphically restricted to the Cordylodus intermedius Zone, Stage 10 of the Furongian. H. simplex is characterized by a simple cone with circular cross-section and a series of spines scattered mainly on the anterior and lateral sides of the base and cusp (Fig. 6n).

The different species of Cordylodus were distinguished by considering the general shape of the elements, the pattern of denticulation (discrete, confluent) and the basal cavity configuration (number of apices, depth, position and shape of its anterior border). As described by Bagnoli, Barnes \& Stevens (1987), the basal cavity of C. caboti (Fig. 6g-i) is not as deep as in C. proavus (Fig. 6a-e), but also extends above the posterior process. Its basal cavity displays a slightly concave to straight anterior margin that
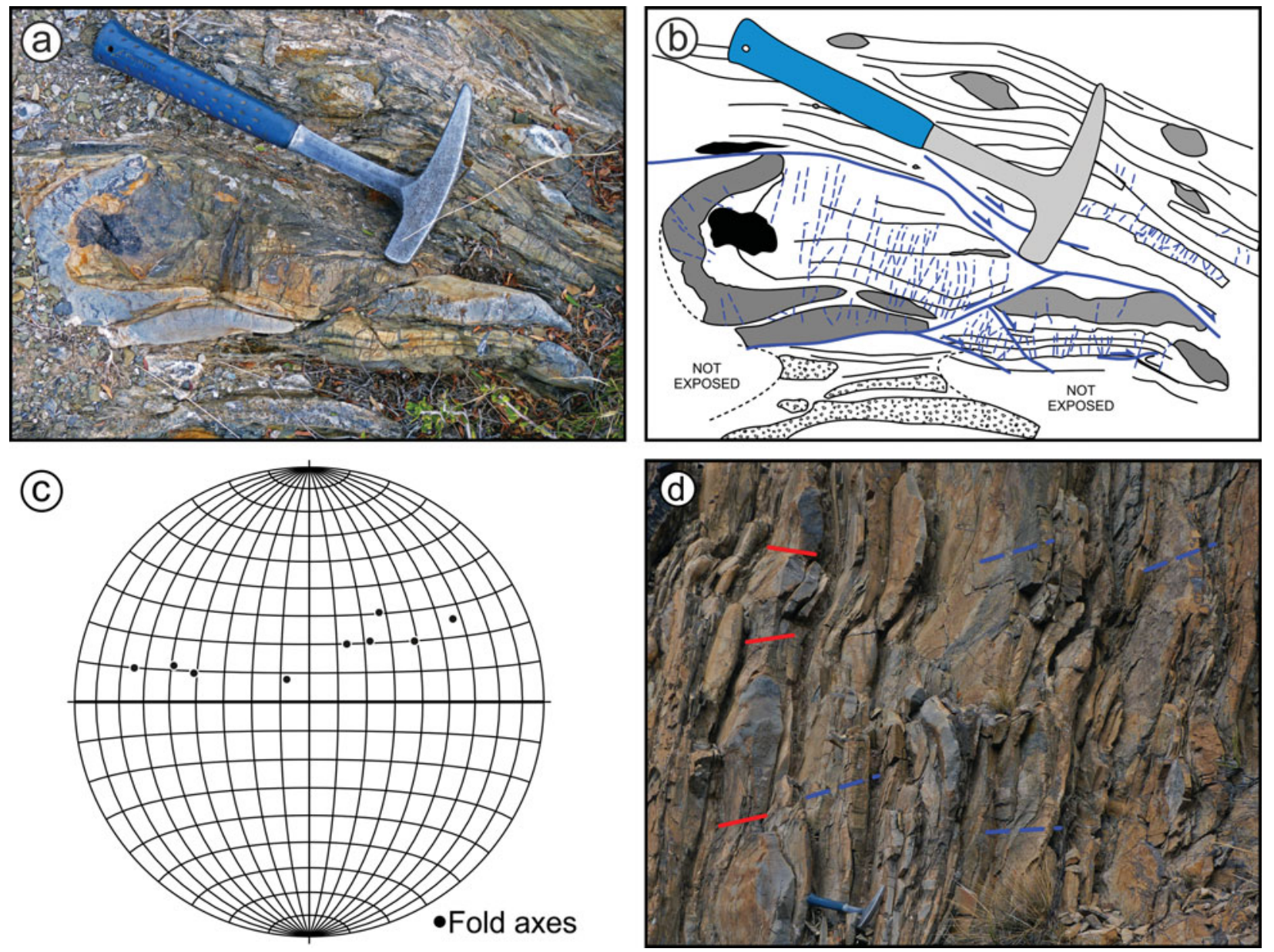

Figure 5. (Colour online) (a, b) Photograph and outcrop sketch showing a slump fold and pinch-and-swell structures in the carbonate succession of the Los Sombreros Formation. Tensional and shear fractures are depicted. See text for explanation, and location in Figure 2. (c) Stereoplot of fold axes in the study area. (d) Boudinaged limestone bed (on the left) and closely spaced microfractures (on the beds located to the right). Hammer for scale: $33 \mathrm{~cm}$. 


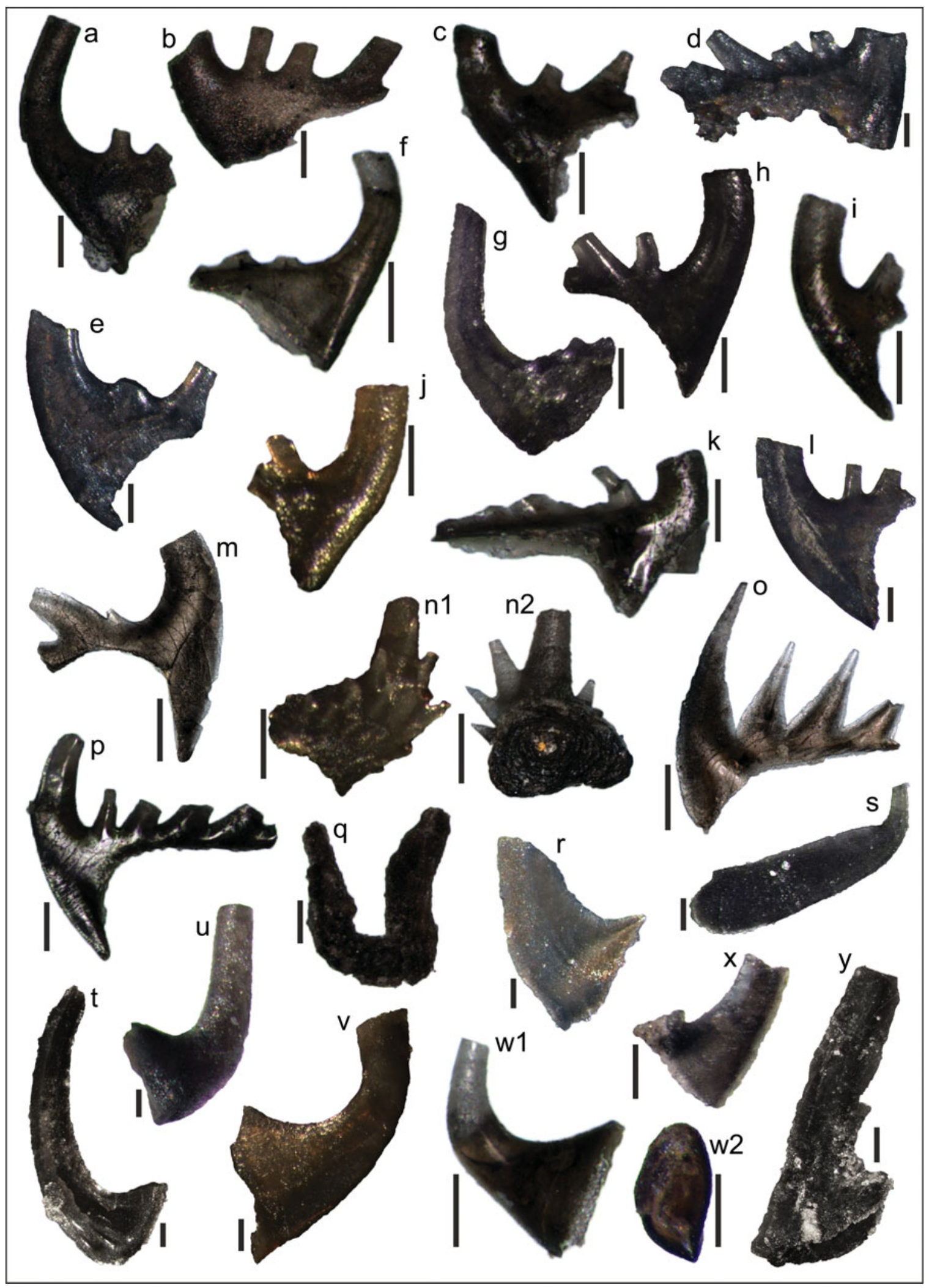

Figure 6. (Colour online) Conodont elements from the Hirsutodontus simplex Subzone of the Cordylodus intermedius Zone (upper Furongian, Cambrian), sample AM6: (a-f) Cordylodus proavus Müller, (a) S element, lateral view, CORD-MP 50734; (b) S element, lateral view, CORD-MP 50735; (c) S element, lateral view, CORD-MP 50736; (d) P element, lateral view, CORD-MP 50737; (e) S element, lateral view, CORD-MP 50738; (f) S element, lateral view, CORD-MP 50739. (g-i) Cordylodus caboti Bagnoli, Barnes \& Stevens, (g) S element, lateral view, CORD-MP 50740; (h) S element, lateral view, CORD-MP 50741; (i) S element, lateral view, CORD-MP 50742. (j) Cordylodus cf. tortus Barnes, S element, lateral view, CORD-MP 50743. (k-m, o, p) Cordylodus intermedius Furnish, (k) S element, lateral view, CORD-MP 50744; (1) S element, lateral view, CORD-MP 50745; (m) S element, lateral view, CORD-MP 50746; (o) M element, lateral view, CORD-MP 50747; (p) S element, lateral view, CORD-MP 50748. (n) Hirsutodontus simplex (Druce \& Jones), CORD-MP 50749, (n1) anterolateral view, (n2) posterior view. (q) Westergaardodina sp., lateral view, 
curves near the tip, with its apex centrally located, which differentiates it from C. intermedius (Nicoll, 1991; Pyle \& Barnes, 2002; Zeballo \& Albanesi, 2009). Miller et al. (2003) regarded C. caboti as a junior synonym of Cordylodus 'drucei' Miller; since we cannot follow his criteria in our collection, we maintain the species $C$. caboti as valid.

The Cordylodus intermedius Zone is divided into a lower Hirsutodontus simplex Subzone and an upper Clavohamulus hintzei Subzone (Miller et al. 2003). The lower subzone begins with the First Appearance Datum (FAD) of $H$. simplex whereas its top is defined by the FAD of $C$. hintzei. The presence of advanced species of Cordylodus in sample AM6, such as C. caboti and $C$. intermedius, which are more frequent in the upper subzone, in the absence of $C$. hintzei, suggests an upper $H$. simplex Subzone for this stratigraphic level (e.g. Ross et al. 1997).

Cordylodus proavus extends from the upper Cambrian up to the Iapetognathus Zone, indicative of the base of the Ordovician, whereas $C$. intermedius and C. caboti reach up to the Rossodus manitouensis Zone (Pyle \& Barnes, 2002). Two elements recovered compare well to the figured forms of Cordylodus cf. andresi sensu Zeballo \& Albanesi (2009) (Fig. 6x), which exhibit a narrower cavity compared to the nominal species (re-illustrated by Miller et al. 2015). Additionally, $C$. andresi occurs in older rocks as it is restricted to the Hirsutodontus hirsutus and Fryxellodontus inornatus zones of the C. proavus Zone. Cordylodus cf. tortus is strongly asymmetric, with a denticle flexed compared to the cusp plane and a basal cavity relatively shallow with its apex slightly displaced to the posterior region (Zeballo \& Albanesi, 2009).

The taxonomy of simple cones is complex, particularly owing to their high variability and subtle diagnostic features. Variabiliconus shares with Teridontus a similar apparatus plan, an abrupt junction between the hyaline base and albid cusp, and the surface microstriation. In particular, Variabiliconus (Oneotodus) datsonensis closely resembles Teridontus nakamurai but is distinguished by the circular basal outline, the upturning of the oral termination of the cusp and the presence of shallow furrows associated with carinas (Druce \& Jones, 1971; Zeballo \& Albanesi, 2009). Miller (1980) reassigned Oneotodus datsonensis Druce \& Jones to T. nakamurai and to Semiacontiodus nogamii Miller. Nicoll (1994) rejected the latter suggestion as well as the emended diagnosis given by Ji \& Barnes (1994a), as they are not applicable to the type species of the genus, which lacks lateral grooves, costae and keels. Tolmacheva \& Abaimova (2009) suggested introducing a new genus for hybrid Teridontus-like species after further investigations. The limited number of specimens recovered does not allow for adequately defining the latitude of morphologic variability of these primitive forms. Therefore, we cautiously assign a simple subsymmetrical coniform element with long cusp to $T$. $n a-$ kamurai (Fig. 6u) and those with short, erect and keeled cusps with weak grooves to $V$. datsonensis, which is restricted to the Furongian (Fig. 6w). Younger species of Variabiloconus are easier to distinguish as they exhibit an increase of ornamentation and development of the cusp (Löfgren, Repetski \& Ethington 1998; Zeballo \& Albanesi, 2013a). The Teridontus nakamurai specimen recovered from the Los Sombreros Formation lacks the typical microstriation of the genus, as previously observed by Lehnert (1994). The genus Orminskia also resembles Teridontus and lacks microstriation, yet it has a hyaline cusp (Landing, Westrop \& Keppie, 2007).

Two samples obtained from thin-bedded fine-grained calciturbidites interbedded with marlstones and breccias located a few metres stratigraphically above AM6 were also productive. Sample AM8A yielded one specimen of Macerodus dianae Fåhraeus \& Nowlan (Fig. 6s), a distinctive form of the standard North American Midcontinent Realm zonation (Ross et al. 1997), whose biostratigraphic range is restricted to a narrow interval of the upper Tremadocian. The M. dianae Zone correlates with the lower part of the upper subzone of the Paltodus deltifer Subzone of the Baltoscandian scheme (Webby et al. 2004). Sample AM8B contains eight elements including Drepanodus arcuatus Pander, Paltodus aff. inaequalis (Pander) (Fig. 6y), Rossodus cf. manitouensis Repetski \& Ethington (Fig. 6r), Scolopodus cf. subrex Ji $\&$ Barnes (Fig. 6t) and a cluster of the paraconodont Phakelodus tenuis (Müller). The S. subrex Zone partly correlates with the Macerodus dianae Zone (Pyle \& Barnes, 2002), whereas Rossodus cf. manitouensis points to a slightly older Ordovician age; yet the available material is not sufficient to verify its taxonomy.

\section{5.c. Conodont palaeoecology and palaeobiogeographic} considerations

The recognition of the Furongian Hirsutodontus simplex Subzone of the Cordylodus intermedius Zone and the Tremadocian Macerodus dianae Zone in the Los Sombreros Formation allows the biostratigraphic correlation between the slope facies and the carbonate-platform domain to be improved, as both

CORD-MP 50750. (u) Teridontus nakamurai (Nogami), S element, lateral view, CORD-MP 50751. (v) Drepanoistodus sp., S element, lateral view, CORD-MP 50752. (w) Variabiloconus datsonensis (Druce \& Jones), CORD-MP 50753, (w1) lateral view, (w2) basal cavity view. (x) Cordylodus cf. andresi Viira \& Sergeyeva, S element, lateral view, CORD-MP 50754. (r-t, y) Conodont elements from the Macerodus dianae Zone (upper Tremadocian, Ordovician): (r) Rossodus cf. manitouensis Repetski \& Ethington, S element, lateral view, sample AM8B, CORD-MP 50755; (s) Macerodus dianae Fåhraeus \& Nowlan, lateral view, sample AM8A, CORD-MP 50756; (t) Scolopodus cf. subrex Ji \& Barnes, lateral view, sample AM8B, CORD-MP 50757; (y) Paltodus aff. inaequalis (Pander), lateral view, sample AM8B, CORD-MP 50758. Scale bar: $0.1 \mathrm{~mm}$. 
zones occur within the La Silla Formation (Lehnert, Miller \& Repetski, 1997). In particular, Albanesi, Cañas \& Mango (in press) described thoroughly the conodont association of the $M$. dianae Zone for the shallow-water carbonates of the La Silla Formation, at the Cerro Viejo de San Roque section. Hirsutodontus simplex, whose biostratigraphic range is restricted to the Cordylodus intermedius Zone, was originally defined in Australia (Druce \& Jones, 1971) and subsequently recovered from China (Chen \& Gong, 1986; Chen et al. 1988), Laurentia (Miller, 1980; Ross et al. 1997; Terfelt, Bagnoli \& Stouge, 2012; Miller et al. 2014), Siberia (Abaimova, 1971, 1975) and NW Argentina (Zeballo \& Albanesi, 2009). Miller (1984) suggested that Clavohamulus and Hirsutodontus had a nektobenthic habit of life and that they preferred warm, shallow seas. The record of Hirsutodontus in the Los Sombreros Formation would then indicate reworking of shallow-water deposits into deep-water facies by gravity flows, as observed in the GSSP for the base of the Ordovician at Green Point, Newfoundland (Cooper, Nowlan \& Williams, 2001; Miller et al. 2014). Accordingly, Clavohamulus hintzei Miller, indicative of the upper subzone of Cordylodus intermedius Zone, is present in the shallow-marine facies of the La Silla Formation, at the eastern domain of the carbonate platform (Lehnert, Miller \& Repetski, 1997).

The species Teridontus nakamurai has been found in several lithofacies suggesting a pelagic habit of life (Ji \& Barnes, 1994b), eventually restricted to the shelf environments owing to a nektobenthic habit (Miller, 1984). After studying a large conodont collection from the Cordillera Oriental, Zeballo \& Albanesi (2013b) recognized an antithetical relationship between the cosmopolitan genera Variabiloconus and Teridontus, verifying that the latter predominates in the deeper parts of the platform. In particular, $V$. datsonensis is present in NE Australia (Druce \& Jones, 1971), Antarctica (Buggisch \& Repetski, 1987) and NW Argentina (Zeballo \& Albanesi, 2009).

The genus Cordylodus was a major component of most slope and platform communities during Furongian and Early Ordovician times. C. proavus has a widespread geographic distribution and is found in a wide range of lithofacies, which suggests a pelagic habit of life. In contrast, $C$. andresi, C. caboti and C. intermedius preferred deeper-water environments (lower proximal to distal slope facies), as younger species of Cordylodus adapted to a nektobenthic mode of life (Miller, 1984; Zhang \& Barnes, 2004).

The $C$. intermedius Zone has a wide global distribution and has been documented in China (Chen \& Gong, 1986), Laurentia (Bagnoli, Barnes \& Stevens, 1987; Barnes, 1988; Miller, 1988; Ross et al. 1997; Miller et al. 2003) and central Asia (Dubinina, 2000). A correlative conodont assemblage has been retrieved from Australia (Druce \& Jones, 1971) and Iran (Müller, 1973). In Argentina, it was previously identified in the Volcancito Formation of the Famatina System (Albanesi et al. 2005) and the Cardonal (Rao, 1999) and
Santa Rosita formations in the Cordillera Oriental (Zeballo \& Albanesi, 2009).

Although conodont provinces can be already distinguished in the late Cambrian (Jeong \& Lee, 2000), most of the palaeogeographic studies are concentrated in the Ordovician, when major realms were already established by late Tremadocian times (Miller, 1984; Charpentier, 1984). Accordingly, the Precordillera is identified as a conodont faunal Province of the Temperate Domain of the Shallow-Sea Realm (or the Open-Sea Realm depending on the sedimentary setting) (Albanesi \& Bergström, 2010; Serra \& Albanesi, 2013), as it lacks the typical shallow-water, tropical forms characteristic of the Laurentian, Australasian or North China provinces (Bagnoli \& Stouge, 1991; Zhen \& Percival, 2003). Instead, it is distinguished by cosmopolitan or widespread faunas, showing a moderate endemism and diversity when compared with faunas from the Tropical Domain. The Baltoscandian Province of the Cold Domain presents lower diversities and higher abundances instead (Zhen \& Percival, 2003).

Macerodus dianae, an index taxon of the late Tremadocian, appeared in sample AM8A. It was first described from outcrops of the Cow Head Group in western Newfoundland, a series of Laurentian slope deposits fed from the outer shelf and the upper continental slope (Fåhraeus \& Nowlan, 1978; Pohler, Barnes \& James, 1987). Ji \& Barnes (1994a) emended its diagnosis with material from the Boat Harbour Formation (St George Group) on the Port au Port Peninsula in western Newfoundland. Macerodus dianae is recognized in widely separated geographic locations of the Great Basin (Ethington \& Clark, 1981; Repetski, 1982; Ross et al. 1997; Landing et al. 2012), the Arctic Archipelago of Canada (G. S. Nowlan, unpub. Ph.D. thesis, Univ. Waterloo, 1976) and northern Norway (Lehnert, Stouge \& Brandl, 2013). In the Kechika Formation of British Columbia, the Macerodus dianae Zone is absent and is substituted by the shallow-water Scolopodus subrex Zone (Pyle \& Barnes, 2002).

Rossodus is a typical genus from the Great Basin, characteristic of the North American Midcontinent Province. The latter is approximately equivalent to the Laurentian Province of the Tropical Domain, in the Shallow-Sea Realm, distinguished by shelf areas $<200 \mathrm{~m}$ in depth with high endemism and diversity (Ethington \& Clark, 1981; Ross et al. 1997; Zhen \& Percival, 2003). Rossodus manitouensis Repetski $\&$ Ethington has also been documented in China $(=$ 'Acodus' oneotensus sensu An, Du \& Gao, 1985; Wang, Bergström \& Lane, 1996), Korea (Seo, Lee \& Ethington, 1994), Thailand (Agematsu et al. 2008) and Tasmania (R. C. Cantrill, unpub. Ph.D. thesis, Univ. Tasmania, 2003). It is also known from the peri-Gondwanan volcanic arc of the Famatina System, where it occurs along with Drepanodus arcuatus, Cornuodus longibasis (Lindström), Paltodus deltifer pristinus (Viira), P. cf. subaequalis Pander and Paroistodus numarcuatus (Lindström), which characterize a biofacies dominated by pelagic species from deep/cold 
waters (Albanesi et al. 2005). In the eastern domain of the Precordillera, Lehnert, Miller \& Repetski (1997) described Rossodus aff. manitouensis from shallowwater facies of the La Silla Formation, along with Aloxoconus cf. propinquus (Furnish), Scolopodus cf.floweri Repetski, Paroistodus numarcuatus and Colaptoconus quadraplicatus (Branson \& Mehl). The authors correlated this conodont assemblage with the Low Diversity Interval and the lower Macerodus dianae conodont biozone in North America (Ross et al. 1997), consistent with the suggested age for the samples AM8A and AM8B from the slope facies of the Los Sombreros Formation.

The record of Macerodus dianae in the slope facies verifies a strong link between the conodont faunas from the Precordillera with those from Laurentia during Early Ordovician times, demonstrating a connection along the borders of the Iapetus Ocean. Accordingly, Lehnert, Miller \& Repetski (1997) interpreted that the record of Clavohamulus hintzei in the $\mathrm{La}$ Silla Formation as well as the faunal similarities at the species level with the shallow-water North American Midcontinent Province was a consequence of the derivation of the Cuyania Terrane from the Ouachita Embayment in Laurentia. Nevertheless, the conodont faunas do not provide clear evidence to postulate a geographic origin for the Precordillera as they show dominantly Laurentian affinities again in the Middle Ordovician, after a gradual immigration of conodonts from colder regions (Albanesi, 1998; Albanesi \& Bergström, 2010).

\section{5.d. Conodont preservation and palaeothermometry}

The Cambrian specimens recovered from sample AM6 are well preserved and exhibit a conodont colour alteration index (CAI) 3 that provides some translucency to the conodont elements. The conodonts present smooth surfaces and scarce mineral overgrowths. Microfractures are frequent and are responsible for the lack of apices on cusps and denticles. Conodonts recovered from samples AM8A and AM8B also exhibit a CAI 3 but display a sugary texture with abundant quartz overgrowths instead. In this case, the different type of textural alteration suggests variations in the intensity of the diagenetic processes.

Interestingly, previous findings of reworked preFloian conodonts recovered from the Los Sombreros Formation display high CAI values in contrast to the elements recovered from the host rock. This fact was interpreted as a result of burial-related metamorphism and exhumation of the carbonate platform near the suture zone of Cuyania with Gondwana, which supplied detritus to the deep-water basin of the Western Precordillera (Voldman, Albanesi \& Ramos, 2009).

The record of Furongian-Lower Ordovician conodonts with CAI 3 ( 110-200 ${ }^{\circ} \mathrm{C}$; Epstein, Epstein \& Harris, 1977) in the Los Sombreros Formation reflects a simpler burial history instead, if a uniform palaeogeothermal gradient in the basin is considered. A rift- related heat source is not possible to discern as CAI values are relatively low, within the range of the observed values in the platform, which can be accounted for solely by sedimentary burial (Voldman, Albanesi \& Ramos, 2010).

Alternatively, the mafic rocks from the Western Precordillera produced very restricted thermal anomalies in the country rocks given the small volume of singlepulsed basalt intrusions, which could only slightly contribute to a regional increment of the heat flux (Voldman, Albanesi \& do Campo, 2008; GonzálezMenéndez et al. 2013). This is consistent with the metamorphic conditions inferred from the paragenetic associations of the mafic rocks, which suggests c. $250-350^{\circ} \mathrm{C}$ and $2-3 \mathrm{kbar}$, with palaeogeothermal gradients of $\sim 30-35^{\circ} \mathrm{C} \mathrm{km}{ }^{-1}$ (Robinson, Bevins \& Rubinstein, 2005), which are typical of mature passive margins and foreland basins (e.g. Allen \& Allen, 2005). Consequently, the CAI 3 in the studied conodont samples reflects a thermal history related to the sedimentary burial and nappe stacking of the Western Precordillera.

\section{Conclusions}

The new conodont data from the Los Sombreros Formation in La Invernada Range along with the sedimentological and structural analysis carried out in the study area show that slope sedimentation and gravity sliding has taken place in the Precordillera since at least late Cambrian times, contrasting with the current hypothesis of a Devonian age for the slope deposits of the Los Sombreros mélange. Moreover, the recognition of the Hirsutodontus simplex Subzone of the Cordylodus intermedius Zone (upper Furongian, Cambrian) and the Macerodus dianae Zone (upper Tremadocian, Ordovician) improves the correlation with the La Silla Formation of the Precordilleran carbonate platform as well as with regions of Gondwana and other palaeocontinents. The record of the index species Macerodus dianae in the Los Sombreros Formation, as well as Clavohamulus hintzei in the La Silla Formation, emphasizes the strong faunal affinity of the shelf environments of the Precordillera with the Laurentian Province of the Tropical Domain for the late Cambrian - Early Ordovician periods. However, given the wide global distribution of the studied specimens, the present data are not indicative of a geographic origin for the Precordillera. The thermal alteration of the studied specimens is consistent with the sedimentary burial and nappe stacking of the Western Precordillera.

Acknowledgements. The authors thank Gian Andrea Pini (Università degli Studi di Trieste) for helping with field work. We appreciate Nigel H. Woodcock and an anonymous reviewer for their constructive suggestions. This study was funded by CONICET, Argentina (RD3646/14, RD2827/15 and PIP 11220130100447CO) and the Ministerio de Economía y Competitividad, Spain (project CGL2012-34475). This paper is also a contribution to the IGCP Project 591.
624 
References

ABAimova, G. P. 1971. New Early Ordovician conodonts from the southeastern part of the Siberian Platform. $\mathrm{Pa}$ leontological Journal 5, 486-93.

ABAIMOVA, G. P. 1975. Early Ordovician conodonts from the middle reaches of the Lena River. Transaction Series of the Siberian Scientific Research Institute for Geology, Geophysics and Mineralogy, Novosibirsk 207, 1-129.

Agematsu, S., SASHIDA, K., SAlYAPONGSE, S. \& SARDSUd, A. 2008. Early Ordovician conodonts from Tarutao Island, southern peninsular Thailand. Palaeontology 51, 1435-53.

Albanesi, G. L. 1998. Biofacies de conodontes de las secuencias ordovícicas del cerro Potrerillo, Precordillera Central de San Juan, R. Argentina. Actas Academia Nacional de Ciencias, Córdoba 12, 75-98.

AlbANESI, G. L. \& BergStröM, S. M. 2010. Early-Middle Ordovician conodont paleobiogeography with special regard to the geographic origin of the Argentine Precordillera: a multivariate data analysis. In The Ordovician Earth System (eds S. C. Finney \& W. B. N. Berry), pp. 119-39. Geological Society of America, Special Paper no. 466.

Albanesi, G. L., CAÑAs, F. \& MANGO, M. In press. Fauna de conodontes tremadocianos del techo de la Formación La Silla en el Cerro Viejo de San Roque, Precordillera Central de San Juan. III Jornadas de Geología de Precordillera, San Juan. Acta Geológica Lilloana.

Albanesi, G. L., Esteban, S. B., Ortega, G., Hünicken, M. A. \& BARNES, C. R. 2005. Bioestratigrafía y ambientes sedimentarios de las formaciones Volcancito y Bordo Atravesado (Cámbrico Superior-Ordovícico Inferior), Sistema de Famatina, provincia de La Rioja, Argentina. In Geología de la provincia de La Rioja: Precámbrico-Paleozoico Inferior (eds J. A. Dahlquist, E. G. Baldo \& P. H. Alasino), pp. 41-64. Buenos Aires: Asociación Geológica Argentina.

Albanesi, G. L., Ortega, G. \& HÜnicken, M. A. 1995. Conodontes y graptolitos de la Formación Yerba Loca (Arenigiano-Llandeiliano) en las quebradas de Ancaucha y El Divisadero, Precordillera de San Juan, Argentina. Boletín de la Academia Nacional de Ciencias, Córdoba 60, 365-400.

Allen, P. A. \& Allen, J. R. 2005. Basin Analysis. Principles and Applications. Oxford: Blackwell Scientific Publications, $560 \mathrm{pp}$.

Allmendinger, R. W., FigueroA, D., Snyder, D., Beer, J., MPODOZIS, C. \& ISACKS, B. L. 1990. Foreland shortening and crustal balancing in the Andes at $30^{\circ} \mathrm{S}$ latitude. Tectonics 9, 789-809.

Alonso, J. L., Gallastegui, J., García-SAnsegundo, J., FARÍAS, P., RODRÍGUEZ-FERNÁNDEZ, L. R. \& RAMOS, V. A. 2008. Extensional tectonics and gravitational collapse in an Ordovician passive margin: the Western Argentine Precordillera. Gondwana Research 13, 204-15.

Alonso, J. L., RodríGUEz FERnÁNDEZ, L. R., GARCÍASAnsegundo, J., Heredia, N., FARias, P. \& GALlASTEGUI, J. 2005. Gondwanic and Andean structure in the Argentine Central Precordillera: the Río San Juan section revisited. In VI International Symposium on Andean Geodynamics, Barcelona. Extended Abstracts (ed. Editorial Board, 12-14 September 2005), pp. 36-9. Paris: IRD Editions, Universitat de Barcelona, Instituto Geológico y Minero de España.

AN, T. X., Du, G. Q. \& GAO, Q. Q. 1985. Study on the Ordovician Conodonts from Hubei. Beijing: Geological Publishing House, 64 pp.
Astini, R. A., Thomas, W. A. \& Yochelson, E. L. 2004. Salterella in the Argentine Precordillera: an Early Cambrian palaeobiogeographic indicator of Laurentian affinity. Palaeogeography, Palaeoclimatology, Palaeoeco$\operatorname{logy} \mathbf{2 1 3}, 125-32$.

Bagnoli, G., Barnes, C. R. \& Stevens, R. K. 1987. Tremadocian conodonts from Broom Point and Green Point, western Newfoundland. Bollettino della Societa Paleontologica Italiana 25(2), 145-58.

Bagnol, G. \& Stouge, S. 1991. Paleogeographic distribution of Arenigian (Lower Ordovician) conodonts. Anais da Academia Brasileira de Ciencias 63, 171-83.

BAldis, B. A., Beresi, M. S., Bordonaro, O. \& VACA, A 1982. Síntesis evolutiva de la Precordillera Argentina. In $V$ Congreso Latinoamericano de Geología, Buenos Aires. Actas 4 (ed. Editorial Board, 17-22 October 1982), pp. 399-445. Buenos Aires: Asociación Geológica Argentina.

Banchig, A. L., Keller, M. \& Milana, J. 1990. Brechas calcáreas de la Formación Los Sombreros, quebrada Ojos de Agua, sierra del Tontal, San Juan. XI Congreso Geológico Argentino, San Juan. Actas 2 (ed. Editorial Board, 17-21 September 1990), pp. 149-52. Buenos Aires: Asociación Geológica Argentina.

BANChIG, A. L. \& MoYA, M. C. 2002. La Zona de Tetragraptus approximatus (Ordovícico Inferior) en la sierra del Tontal, Precordillera occidental Argentina. VIII Congreso Argentino de Paleontología y Bioestratigrafía, Corrientes. Resúmenes (ed. Editorial Board, 7-10 October 2002), 83 pp. Buenos Aires: Asociación Paleontológica Argentina.

BARNES, C. R. 1988. The proposed Cambrian-Ordovician global Boundary stratotype and point (GSSP) in Western Newfoundland, Canada. Geological Magazine 125, 381-414.

BENEDETTO, J. L. \& VACCARI, E. 1992. Significado estratigráfico y tectónico de los complejos de bloques cambroordovícicos resedimentados de la Precordillera Occidental Argentina. Estudios Geológicos 48, 305-13.

BORDONARO, O. 2003. Review of the Cambrian stratigraphy of the Argentine Precordillera. Geologica Acta 1, 11-21.

BORDONARO, O. \& BALDIS, B. A. 1987. Tonkinella stephensis (Trilobita) en el Cámbrico medio de la Sierra del Tontal, San Juan, Argentina. IV Congreso Latinoamericano de Paleontología, Santa Cruz de La Sierra. Actas 1 (ed. Editorial Board, 27-30 July 1987), pp. 5-15. Santa Cruz de la Sierra: Asociación Boliviana de Paleontología.

BORDONARO, O. \& BANCHIG, A. L. 1990. Nuevos trilobites del Cámbrico medio en la Qa. Ojos de Agua, Sa. del Tontal, San Juan. Serie de Correlación Geológica 7, 25-37.

BugGisch, W. \& REPETSKI, J. E. 1987. Uppermost Cambrian (?) and Tremadocian conodonts from Handler Ridge (Robertson Bay terrane, northern Victoria Land, Antarctica). Geologisches Jahrbuch 66, 145-85.

CAWOOD, P. A. 2005. Terra Australis Orogen: Rodinia breakup and development of the Pacific and Iapetus margins of Gondwana. Earth-Science Reviews 69, 249-79.

Charpentier, R. R. 1984. Conodonts through time and space: studies in conodont provincialism. In Conodont Biofacies and Provincialism (ed. D. L. Clark), pp. 1132. Geological Society of America, Special Paper no. 196.

Chen, J. \& Gong, W. 1986. Conodonts. In Aspects of Cambrian-Ordovician Boundary in Dayangcha, China (ed. J.-Y. Chen.), pp. 93-223. Beijing: China Prospect Publishing House. 
CHEN, J.-Y., QIAN, Y.-Y., ZHANG, J.-M., LIN, Y.-K., YIN, L.M., WANG, Z.-H., WANG, Z.-Z., YANG, J.-D. \& WANG, Y.-X. 1988. The recommended Cambrian-Ordovician global boundary stratotype of the Xiaoyangqiao section (Dayangcha, Jilin Province, China). Geological Magazine 125, 415-44.

CoOper, R. A., Nowlan, G. S. \& Williams, S. H. 2001. Global Stratotype Section and Point for base of the Ordovician System. Episodes 24, 19-28.

Cuerda, A. J., Cingolani, C. A. \& Varela, R. 1983. Las graptofaunas de la Formación Los Sombreros, Ordovícico inferior de la vertiente oriental de la sierra del Tontal. Ameghiniana 30, 239-60.

Cuerda, A. J., Cingolani, C., Varela, R. \& Schauer, O. 1986. Cámbrico y Ordovícico en la Precordillera de San Juan: Formación Los Sombreros, ampliación de su conocimiento bioestratigráfico, IV Congreso Argentino de Bioestratigrafía y Paleontología, Mendoza. Actas 1 (ed. A. Cuerda, 23-27 November 1986), pp. 5-17. Mendoza: Inca.

Cuerda, A., Cingolani, C. A., Varela, R., Schauer, O., BAldis, B. A. \& BordonARO, O. L. 1985. Hallazgo de sedimentitas Cámbricas fosilíferas en la Sierra de Tontal (Precordillera de San Juan). Ameghiniana 22, 281-2.

DRUCE, E. C. \& JoneS, P. J. 1971. Cambro-Ordovician conodonts from the Burke River Structural Belt, Queensland. Bureau of Mineral Resources, Geology and Geophysics Bulletin 110, 1-159.

DuBININA, S. V. 2000. Conodonts and Zonal Stratigraphy of the Cambrian-Ordovician Boundary Deposits. Transactions of the Geological Institute of the USSR Academy of Sciences no. 517. Moscow: Nauka, 240 pp.

Epstein, A. G., Epstein, J. B. \& HARris, L. D. 1977. Conodont Color Alteration - An Index to Organic Metamorphism. Geological Survey Professional Paper no. 995, 27 pp.

Ethington, R. L. \& ClARK, D. L. 1981. Lower and Middle Ordovician Conodonts from the Ibex Area, Western Millard County, Utah. Brigham Young University Geology Studies 28, 1-160.

FÅHRÆUS, L. E. \& NowLAN, G. S. 1978. Franconian (Late Cambrian) to Early Champlainian (Middle Ordovician) conodonts from the Cow Head Group, Western Newfoundland. Journal of Paleontology 52, 444-71.

FurQue, G. \& CABALlÉ, M. 1988. Descripción Geológica de la Sierra de La Invernada, Precordillera de San Juan. Buenos Aires: Dirección Nacional de Geología y Minería, $76 \mathrm{pp}$.

Furque, G., Cuerda, A. J., Caballé, M. \& Alfaro, M. 1990. El Ordovícico de la Sierra de la Invernada y su fauna de graptolitos, San Juan. Revista del Museo de la Plata (N.S.) Paleontología 9, 159-81.

GonzÁlez-MenÉndez, L., Gallastegui, G., Cuesta, A., Heredia, N. \& Rubio-OrdóñEZ, A. 2013. Petrogenesis of Early Paleozoic basalts and gabbros in the western Cuyania terrane: constraints on the tectonic setting of the southwestern Gondwana margin (Sierra del Tigre, Andean Argentine Precordillera). Gondwana Research 24, 359-76.

Gosen, W. VON. 1992. Structural evolution of the Argentine Precordillera: the Río San Juan section. Journal of Structural Geology 14, 643-67.

HeIM, A. 1952. Estudios tectónicos en la Precordillera de San Juan. Revista de la Asociación Geológica Argentina 7, 11-74.

Heredia, S. E. \& Beresi, M. S. 2004. La Formación Empozada y su relación estratigráfica con la Formación Estancia San Isidro (nom. nov.), Ordovícico de la Precor- dillera de Mendoza. Revista de la Asociación Geológica Argentina 59, 178-92.

JeOnG, H. \& LEE, Y. I. 2000. Late Cambrian biogeography: conodont bioprovinces from Korea. Palaeogeography, Palaeoclimatology, Palaeoecology 162, 119-36.

Ji, Z. \& BARNES, C. R. 1994a. Lower Ordovician conodonts of the St. George Group, Port au Port Peninsula, western Newfoundland, Canada. Palaentographica Canadiana 11, 1-149.

Ji, Z. \& BARNES, C. R. 1994b. Conodont paleoecology of the Lower Ordovician St. George Group, Port au Port Peninsula, Western Newfoundland. Journal of Paleontology 68, 1368-83.

KELLER, M. 1999. Argentine Precordillera: Sedimentary and Plate Tectonic History of a Laurentian Crustal Fragment in South America. Geological Society of America, Special Paper no. 341, 131 pp.

LANDing, E., Adrain, J. M., Westrop, S. R. \& KRÖGER, B. 2012. Tribes Hill-Rochdale formations in east Laurentia: proxies for Early Ordovician (Tremadocian) eustasy on a tropical passive margin (New York and west Vermont). Geological Magazine 149, 93-123.

LANDING, E., WeSTROP, S. R. \& KePPIE, J. D. 2007. Terminal Cambrian and lowest Ordovician succession of Mexican West Gondwana: biotas and sequence stratigraphy of the Tiñú Formation. Geological Magazine 144, 909-36.

LEHNERT, O. 1994. A Cordylodus proavus fauna from West Central Argentina (Los Sombreros Formation, Sierra del Tontal, San Juan). Zentralblatt für Geologie und Paläentologie 1, 245-62.

Lehnert, O., Miller, J. F. \& Repetski, J. E. 1997. Paleogeographic significance of Clavohamulus hintzei Miller (Conodonta) and other Ibexian conodonts in an early Paleozoic carbonate platform facies of the Argentine Precordillera. Geological Society of America Bulletin 109, 429-43.

Lehnert, O., Stouge, S. \& Brandl, P. A. 2013. Conodont biostratigraphy in the Early to Middle Ordovician strata of the Oslobreen Group in Ny Friesland, Svalbard. Zeitschrift der Deutschen Gesellschaft für Geowissenschaften 164, 149-72.

LÖFgren, A., Repetski, J. E. \& Ethington, R. L. 1998. Some trans-Iapetus conodont faunal connections in the Tremadocian. Bolletino della Società Paleontologica Italiana 37, 159-73.

LOWE, D. R. 1982. Sediment gravity flows: II. Depositional models with special reference to the deposits of highdensity turbidity currents. Journal of Sedimentary Petrology 52, 279-97.

MCILreath, J. A. \& JAMES, N. P. 1984. Carbonate slopes. In Facies Models (ed. R. G. Walker), pp. 245-57. Geoscience Canada, Reprint Series no. 1.

MILLER, J. F. 1980. Taxonomic revisions of some Upper Cambrian and Lower Ordovician conodonts with comments on their evolution. University of Kansas Paleontological Contributions 99, 1-44.

MILLER, J. F. 1984. Cambrian and earliest Ordovician conodont evolution, biofacies, and provincialism. In Conodont Biofacies and Provincialism (ed. D. L. Clark), pp. 43-68. Geological Society of America, Special Paper no. 196.

MiLLER, J. F. 1988. Conodonts as biostratigraphic tools for redefinition and correlation of the Cambrian-Ordovician boundary. Geological Magazine 125, 349-62.

Miller, J. F., DAtTilo, B. F., Ethington, R. L., FreEman, R. L. 2015. Polyfocal photography of conodonts and other microfossils using petrographic microscopes. Annales de Paléontologie 101, 179-84. 
Miller, J. F., Evans, K. R., Loch, J. D., Ethington, R. L., STITT, J. H., HOLMER, L. \& POPOV, L. 2003. Stratigraphy of the Sauk II interval (Cambrian-Ordovician) in the Ibex area, western Millard County, Utah, and central Texas. Brigham Young University Geology Studies 47, 23-118.

Miller, J. F., RePetski, J. E., Nicoll, R. S., Nowlan, G. \& ETHINGTON, R. L. 2014. The conodont Iapetognathus and its value for defining the base of the Ordovician System. Geologiska Föreningens $i$ Stockholm Förhandlingar 136, 185-8.

MüLlER, K. J. 1973. Late Cambrian and Early Ordovician conodonts from northern Iran. Geological Survey of Iran Report 30, 1-77.

Mutti, E., Tinterri, R., Remacha, E., Mavilla, N., Agnella, S. \& FAVA, L. 1999. An introduction to the analysis of ancient turbidite basins from an outcrop perspective. American Association of Petroleum Geologists Continuing Education Course Note Series 39, 1-93.

NiCOLL, R. S. 1991. Differentiation of Late Cambrian Early Ordovician species of Cordylodus (Conodonta) with biapical basal cavities. BMR Journal of Australian Geology \& Geophysics 12, 223-44.

NiCOLL, R. S. 1994. Seximembrate apparatus structure of the Late Cambrian coniform conodont Teridontus nakamurai from the Chatsworth Limestone, Georgina Basin, Queensland. AGSO Journal of Australian Geology and Geophysics 15, 367-79.

Ortega, G., Albanesi, G. L., Banchig, A. \& Peralta, G. L. 2008. High resolution conodont-graptolite biostratigraphy in the Middle-Upper Ordovician of the Sierra de La Invernada Formation (Central Precordillera, Argentina). Geologica Acta, 6, 161-80.

Ortega, G., Albanesi, G. L., Heredia, S. E. \& Beresi, M. S. 2007. Nuevos registros de graptolitos y conodontes ordovícicos de las formaciones Estancia San Isidro y Empozada, Quebrada San Isidro, Precordillera de Mendoza. Ameghiniana 44, 697-718.

Ortega, G., Banchig, A. L., Voldman, G. G., Albanesi, G. L., Alonso, J. L., Festa, A. \& CARdó, R. 2014. Nuevos registros de graptolitos y conodontes en la Formación Los Sombreros (Ordovícico), Precordillera de San Juan, Argentina, y su implicancia geológica. XIX Congreso Geológico Argentino, Córdoba. Actas CDROM (ed. Editorial Board, 2-6 June 2014). Córdoba: Asociación Geológica Argentina.

OrtiZ, A. \& Zambrano, J. J. 1981. La Provincia Geológica Precordillera Oriental. VIII Congreso Geológico Argentino, San Luis. Actas, 3 (ed. Editorial Board, 20 26 September 1981), 59-74. Buenos Aires: Asociación Geológica Argentina.

PERALTA, S. H. 2013. Devónico de la sierra de La Invernada, Precordillera de San Juan, Argentina: revisión estratigráfica e implicancias paleogeográficas. Revista de la Asociación Geológica Argentina 70, 202-15.

Pohler, S. L., BARNeS, C. R. \& JAMES, N. P. 1987. Reconstruction of a lost faunal realm: conodonts from breccia beds of the Lower Ordovician Cow Head Group, western Newfoundland. In Conodonts: Investigative Techniques and Applications (ed. R. L. Austin), pp. 341-62. Chichester: Ellis Horwood Limited.

PyLE, J. L. \& BARNES, C. R. 2002. Taxonomy, Evolution, and Biostratigraphy of Conodonts from the Kechika Formation, Skoki Formation, and Road River Group (Upper Cambrian to Lower Silurian), Northeastern British Columbia. Ottawa: NRC Research Press, 227 pp.

RAmos, V. A. 1995. Sudamérica: un mosaico de continentes y océanos. Ciencia Hoy 6, 24-9.
Ramos, V. A., Cristallini, E. O. \& Pérez, D. J. 2002. The Pampean flat-slab of the Central Andes. Journal of South America Earth Sciences 15, 59-78.

RAmos, V. A., VuJOVich, G. I. \& DALlmeyeR, R. D. 1996. Los klippes y ventanas tectónicas preándicas de la sierra de Pie de Palo (San Juan): edad e implicaciones tectónicas. XIII Congreso Geológico Argentino y III Congreso de Exploración de Hidrocarburos, Buenos Aires. Actas 5 (ed. Editorial Board, 13-18 October 1996), pp. 377-91. Buenos Aires: Asociación Geológica Argentina.

RAO, R. I. 1999. Los conodontes cambro-ordovícicos de la sierra de Cajas y del Espinazo del Diablo, Cordillera Oriental, República Argentina. Revista Española de Micropaleontologia 31, 23-51.

Rapela, C. W., Verdecchia, S. O., Casquet, C., PANKhURST, R. J., BALDO, E. G., GALINDO, C., MURRA, J. A., DAHLQUist, J. A. \& FANNING, C. M. 2016. Identifying Laurentian and SW Gondwana sources in the Neoproterozoic to Early Paleozoic metasedimentary rocks of the Sierras Pampeanas: paleogeographic and tectonic implications. Gondwana Research 32, 193-212.

REPETSKI, J. E. 1982. Conodonts from El Paso Group (Lower Ordovician) of westernmost Texas and southern New Mexico. New Mexico Bureau of Mines \& Mineral Resources Memoir 40, 1-121.

Robinson, D., Bevins, R. E. \& Rubinstein, N. 2005. Subgreenschist facies metamorphism of metabasites from the Precordillera terrane of western Argentina; constraints on the later stages of accretion onto Gondwana. European Journal of Mineralogy 17, 441-52.

Ross, R. J. JR., Hintze, L. F., Ethington, R. L., MilleR, J. F., TAYLOR, M. E. \& REPETSKI, J. E. 1997. The Ibexian, Lowermost Series in the North American Ordovician. U. S. Geological Survey Professional Paper 1579-A, $1-50$.

SeO, K.-S., LeE, H.-Y. \& Ethington, R. L. 1994. Early Ordovician Conodonts from the Dumugol Formation in the Baegunsan Syncline, Eastern Yeongweol and Samcheog Areas, Kangweon-Do, Korea. Journal of Paleontology 68, 599-616.

Serra, F. \& Albanesi, G. L. 2013. Paleoecology and paleobiogeography of Darriwilian conodonts from the Las Chacritas Formation, Central Precordillera of San Juan, Argentina. In Conodonts from the Andes (ed. G. L. Albanesi \& G. Ortega), pp. 103-8. Asociación Paleontológica Argentina, Publicación Especial no. 13.

STONE, J. 1987. Review of investigative techniques used in the study of conodonts. In Conodonts: Investigative Techniques and Applications (ed. R. L. Austin), pp. 17-34. Chichester: Ellis Horwood Limited.

Terfelt, F., BagnOLI, G. \& Stouge, S. 2012. Re-evaluation of the conodont Iapetognathus and implications for the base of the Ordovician System GSSP. Lethaia 45, 22737.

TolmacheVA, T. J. \& ABAimova, G. P. 2009. Late Cambrian and Early Ordovician Conodonts from the Kulumbe River Section, Northwest Siberian Platform. Memoirs of the Association of Australasian Palaeontologists 37, 427-51.

Voldman, G. G., Albanesi, G. L. \& DO CAMPO, M. 2008. Conodont palaeothermometry of contact metamorphism in Middle Ordovician rocks from the Precordillera of western Argentina. Geological Magazine 145, 44962.

Voldman, G. G., Albanesi, G. L. \& Ramos, V. A. 2009. Ordovician metamorphic event in the carbonate platform of the Argentine Precordillera: implications for 
1066 the geotectonic evolution of the proto-Andean margin of 1067 Gondwana. Geology 37, 311-4.

1068 Voldman, G. G., Albanesi, G. L. \& Ramos, V. A. 2010. 1069 Conodont geothermometry of the lower Paleozoic from 1070 the Precordillera (Cuyania terrane), northwestern Ar1071 gentina. Journal of South America Earth Sciences 29, 1072 278-88.

1073 Voldman, G. G., Alonso, J. L., Albanesi, G. L., BAnchiG, 1074 A. L., ORTEGA, G., RodríGUEZ FERNÁNDEZ, L. R. \& 1075 FESTA, A. 2014. New conodont records from the Los 1076 Sombreros Formation, an Ordovician mélange in the 1077 Argentine Precordillera. Gondwana 15, Madrid. Ab1078 stracts (eds R. J. Pankhurst, P. Castiñeiras \& S. Sánchez 1079 Martínez, 14-18 July 2014), 170 pp. Madrid: Instituto 1080 Geológico y Minero de España.

1081 Wang, Z. H., Bergström, S. M. \& Lane, H. R. 1996. 1082 Press.
Zeballo, F. J. \& Albanesi, G. L. 2009. Conodontes cámbricos y Jujuyaspis keideli Kobayashi (Trilobita) en el Miembro Alfarcito de la Formación Santa Rosita, quebrada de Humahuaca, Cordillera Oriental de Jujuy. Ameghiniana 46, 537-56.

Zeballo, F. J. \& Albanesi, G. L. 2013a. New conodont species and biostratigraphy of the Santa Rosita Formation (upper Furongian-Tremadocian) in the Tilcara Range, Cordillera Oriental of Jujuy, Argentina. Geological Journal 48, 170-93.

Zeballo, F. J. \& Albanesi, G. L. 2013b. Biofacies and palaeoenvironments of conodonts in Cambro-Ordovician sequences of the Quebrada de Humahuaca, Cordillera Oriental of Jujuy, Argentina. Geological Journal 48, 194-211.

ZHANG, S. \& BARNES, C. R. 2004. Late Cambrian and Early Ordovician conodont communities from platform and slope facies, western Newfoundland: a statistical approach. In The Palynology and Micropalaeontology of Boundaries (eds A. B. Beaudoin \& M. J. Head), pp. 4772. Geological Society of London, Special Publication no. 230.

ZHEN, Y.-Y. \& PERCIVAL, I. A. N. 2003. Ordovician conodont biogeography - reconsidered. Lethaia 36, 357-69.
1090

1091

1092

1093

1094

1095

1096

1097

1098

1099

1100

1101

1102

1103

1104

1105

1106

1107

1108

1109

1110

1111

1112 cival), pp. 41-7. New York: Columbia University 